\title{
EKSEKUSI JAMINAN FIDUSIA SETELAH PUTUSAN MAHKAMAH KONSTITUSI NOMOR 18/PUU/XVII/2019)
}

\author{
Syafrida, Ralang Hartati \\ Fakultas Hukun Universitas Tama jagakarsa \\ E-mail: syafrida_01@yahoo.com
}

\begin{abstract}
ABSTRAK
Fidusia hak kebendaan bersifat memberikan jamina. Objek jaminannya benda bergerak berwujud, tidak berwujud dan benda tidak bergerak yang tidak dapat dijamin dengan hak tanggungan. Jaminan fidusia banyak digunakan oleh perusasaan pembiayaan. Debitur wanprestasi, pihak leasing mengeksekusi objek fidusia secara sepihak, hal ini dianggap bertentangan dengan UUD Tahun 1945. Pasal 15 ayat (2) dan Pasal 15 ayat (3) Undang -Undang Nomor 42 Tahun 1999 tentang Jaminan Fidusia dilakukan uji materil. Rumusan masalah, bagaimana eksekusi jaminan fidusia setelah putusan Mahkamah Konstitusi No. 18/PUUXVII/2019. Metode penelitian, mengunakan penelitian kepustakaan berupa data sekunder. Penelitian bersifat Yuridis Normatif dan jenis penelitian kualitatif. Pembahasan setelah putusan Mahkamah Konstitusi No. 18/PUU-XVII/2019 menyatakan Pasal 15 ayat (2) dan Pasal 15 ayat (3) Undang-Undang Nomor 42 Tahun 1999 bertentangan dengan UUD tahun 1945. Kesimpulan, sebelum putusan Mahkamah Konstitusi eksekusi objek jaminan fidusia berdasarkan Pasal 29 Undang-Undang Nomor 42 Tahun 1999 tentang Jaminan Fidusia.. Setelah Putusan Mahkamah Konstitusi No. 18/PUU-XVII/2019 menyatakan eksekusi jaminan tidak dapat dilakukan secara sepihak oleh kreditur, tapi harus melalui putusan Pengadilan Negeri, kecuali ada kesepakatan mengenai cidera janji antara debitur dengan kreditur dan debitur menyerahkan secara sukarela objek jaminan fidusia. Saran, Otoritas Jasa Keuagan (OJK) memberikan sanksi kepada lembaga pembiayaan yang melakukan eksekusi sepihak objek jaminan.
\end{abstract}

Kata Kunci: eksekusi, objek jaminan, fidusia

\begin{abstract}
Fiduciary material rights are guaranteed. The collateral objects are tangible, intangible and immovable objects that cannot be guaranteed with mortgages. Fiduciary collateral is widely used by finance companies. Debtor defaults, the leasing party executes fiduciary objects unilaterally, this is considered contrary to the 1945 Constitution. Article 15 paragraph (2) and Article 15 paragraph (3) of Law Number 42 of 1999 concerning Fiduciary Guarantee is subjected to a material test. Formulation of the problem, how the execution of fiduciary guarantees after the decision of the Constitutional Court No. 18 / PUU-XVII / 2019. Research methods, using literature research in the form of secondary data. The research is normative juridical and qualitative research type. Discussion after the decision of the Constitutional Court No. 18 / PUU-XVII / 2019 states that Article 15 paragraph (2) and Article 15 paragraph (3) of Law Number 42 Year 1999 is contradictory to the 1945 Constitution. Conclusions, prior to the
\end{abstract}


decision of the Constitutional Court the execution of fiduciary security object based on Article 29 of the Law Number 42 of 1999 concerning Fiduciary Security .. After the Constitutional Court's Decision No. 18 / PUU-XVII / 2019 states that the execution of guarantees cannot be carried out unilaterally by creditors, but must be through a District Court decision, unless there is an agreement on breach of contract between the debtor and the creditor and the debtor voluntarily submits the object of fiduciary collateral. Suggestions, the Financial Services Authority (OJK) provides sanctions to financial institutions that carry out unilateral executions of collateral objects.

Keywords: exclusion, collateral object, fiduciary

\section{PENDAHULUAN}

Pembangunan ekonomi merupakan bagian dari pembangunan nasional yang merupakan salah satu upaya untuk mencapai masyarakat adil dan makmur berdasarkan Pancasila dan Undang-Undang Dasar Tahun 1945. Dalam rangka memelihara dan meneruskan kesinambungan pembangunan ekonomi dan kegiatan bisnis para pelaku usaha baik pemerintah maupun masyarakat, baik perorangan maupun badan hukum memerlukan dana besar. Seiring dengan meningkatnya kegiatan pembangunan meningkat pula kebutuhan terhadap pendanaan yang sebagian besar diperoleh dari kegiatan pinjam meminjam. ${ }^{1}$

Fiduciare Eigendom Overdracht atau lazim disebut Fidusia berasal dari kata "fides" yang berarti kepercayaan. ${ }^{2}$ Fidusia merupakan salah salah satu lembaga jaminan, hak kebendaan yang bersifat memberikan jaminan. Timbulnya fidusia karena kebutuahn masyarakat akan kredit dengan jaminan benda bergerak, tetapi masih memerlukan benda-benda tersebut untuk dipakai sendiri.Fidusia merupakan perjanjian ikutan yang lahir dari suatu perjanjian pokok yang menimbulkan kewajiban bagi para pihak untuk memenuhi prestasi (Pasal 4) Undang-Undang Nomor 42 Tahun 1999 tentang Jaminan Fidusia. Timbulnya fidusia didahului oleh suatu perjanjian pinjam meminjam uang atau perjanjian utang piutang sebagai perjanjian pokok. Selanjutnya sebagai jaminan pelunasan hutang dibuatlah dibuatlah suatu perjanjian tambahan/ perjanjian ikutan berupa perjanjian dengan jaminan fidusia. Apabila perjanjian pokoknya dilunasi, maka

\footnotetext{
${ }^{1}$ Penjelasan Undang-Undang Nomor 42 Tahun 1999 tentang Jaminan Fidusia.

${ }^{2}$ Frieda Husnis Hasbullah, Hukum Kebendaan Perdata, Cet.2, ( Jakarta: Ind-Hill-Co, 2005), hlm. 43.
} 
perjanjian tambahan berupa perjanjian jaminan fidusia otomatis akan berakhir pula. Lahir dan berakhirnya perjanjian jaminan fidusia tergantung kepada perjanjian pokoknya hutang piutang.

Fidusia merupakan hak kebendaan yang hanya bersifat memberikan jaminan pelunasan hutang. Jika hutang debiturnya telah lunas, maka perjanjian fidusianya akan berakhir pula. Benda yang dijadikan jaminan fidusia tetap dikuasai oleh pihak debitur atau pemberi fidusia, walaupun hak milik atas benda telah berpindah kepada kreditur. Apabila debitur dinyatakan pailit, maka objek fidusia tidak menjadi boedel pailit. Kurator pailit tidak berhak menuntut objek jaminan fidusia dari pemberi fidusia. Kreditur penerima fidusia mempunyai hak preperen karena mempunyai kedududkan separatis apabila debitur pemberi fidusia cidera janji. Kreditur penerima fidusia berhak untuk menjual objek jaminan fidusia sebagai jaminan pelunasan hutang yang didahulakan dari kreditur-kreditur lainnya.

Pasal 1 angka (1) Undang-Undang Nomor 42 Tahun 1999 tentang Jaminan Fidusia, menyatakan Fidusia adalah pengalihan hak kepemilikan suatu benda atas dasar kepercayaan dengan ketentuan bahwa benda yang hak kepemilikannya dialihkan tersebut tetap dalam penguasaan pemilik benda. Jadi yang dialihkan adalah kepemilikan atas benda yang dijadikan objek jaminan fidusia, sedangkan bendanya tetap dikuasai oleh debitur pemberi fidusia. Terbitnya Undang-Undang Nomor 42 Tahun 1999 tentang Jaminan Fidusia untuk memacu aktifitas perekonomian dengan jaminan kepastian hukum terutama bagi pengusaha kecil dalam menghadapi ekonomi global, persaingan usaha, sehingga pengusaha kecil tersebut diharapkan dapat bertahan dan tidak mudah terpengaruh dalam menghadapi perubahan perekonomian yang sangat pesat dan semakin komplek. ${ }^{3}$

Fidusia sebagai hak kebendaan yang bersifat memberikan jaminan sudah dikenal sejak zamamn Romawi, fidusia berasal dari kata "fides" yang berarti kepercayaan. Hubungan debitur atau pemberi fidusia dengan kreditur atau penerima fidusia merupakan hubungan hukum berdasarkan kepercayaan. Pemberi fidusia atau debitur percaya, bahwa penerima fidusia atau kreditur mau mengembalikan hak milik terhadap barang yang diserahkan kepadanya, setelah

${ }^{3}$ Andreas Albertus Andi Prajitno. Hukum Fidusia, Cet. 1, ( Malang: Selaras, 2010), hlm. 
utang dilunasinya. Sebaliknya penerima fidusia atau kreditur percaya, bahwa pemberi fidusia atau debitur tidak akan menyalah gunakan objek jaminan yang berada dalam kekuasaannya. ${ }^{4}$

Fidusia merupakan pengalihan hak kepemilikan sebuah benda dimana hak kepemilikannya benda tersebut masih dalam pengusahaan pemilik benda.. Contohnya membeli motor dengan kredit, maka pihak pemberi kredit akan membeli kepada dealer, maka motor tersebut adalah pemilik pemberi kredit dan hak miliknya dialihkan kepada debitur berdasarkan kepercayaan.

Pasal 1 ayat (1) Undang-Undang Nomor 42 Tahun 1999 tentang Jaminan Fidusia menyatakan, Fidusia adalah pengalihan kepemilikan suatu benda atas dasar kepercayaan dengan ketentuan, bahwa benda yang hak kepemilikannya dialihkan tersebut tetap dalam pengusaan pemilik benda. Berdasarkan Pasal 1 angka 2 tersebut perusahaan leasing menjalankan bisnisnya mengunakan jaminan fidusia. Perusahaan leasing memberikan kredit kendaraan bermotor atau mobil kepada debitur (penerima kredit) sebagai jaminan adalah kendaraan, diserahkan hak kepemilikan kepada debitur atau penerima kredit berdasarkan kepercayaan. Perjanjian antara perusahaan leasing debitur atau penerima kredit diikat dengan suatu perjanjian baku yang ditentukan secara sepihak oleh perusahaan leasing. Perjanjian baku yang ditentukan secara sepihak oleh perusahaan leasing tidak ada posisi tawar menawar antara perusahaan keasing (kreditur) dengan debitur. Jika debitur menanda tangani perjanjian leasing, maka lahirlah perjanjian dan para pihak terikat dengan perjanjian yang telah ditanda tangani.

Sejak terjadi kesepakatan pada perjanjian leasing, kendaraan telah beralih hak kepemilikan kepada penerima kredit berdasarkan kepercayaan dari pemberi kredit (leasing) dan debitur (penerima kredit). Jika debitur (penerima kredit) melakukan wanprestasi, maka perusahaan leasing ( pemberi kredit) dapat melakukan eksekusi objek jaminan kredit berdasarkan Pasal 29 Undang-Undang Nomor 42 tahun 1999 tentang jaminan Fidusia. Namun kenyataan banyak perusahaan leasing sebagai pemberi kredit dalam melakukan eksekusi objek jaminan ketika terjadi cidera janji tidak sesuai prosedur hukum yang berlaku. Perusahaan leasing sebagai Pemberi kredit melakukan eksekusi secara sepihak hlm .119.

${ }^{4}$ Gunawan Widjaya \& Ahmad Yani, Jaminan Fidusia, ( Jakarta: RajaGrafindo, 2007), 
tanpa pemberitahuan terlebih dahulu saat debitur harus melakukan wanprestasi. Kreditur ( leasing) melakukan tindakan sewenang-wenang, manarik kendaraan sebagai objek jaminan fidusia secara paksa dengan mengunakan jasa deb kolektor yang mengarah perbuatan pidana. Debitur yang wanprestasi berhadapan dengan deb kolektor yang harus menyerahkan kendaraannya secara paksa kepada deb kolektor. Debitur yang berada pada posisi yang lemah tidak seimbang dengan kreditur pada posisi yang kuat secara ekonomi berhadapan dengan dengan deb kolektor yang disewa jasanya oleh perusahaan leasing.

Kasus yang terjadi pada salah satu mahasiswa saya, dalam kondisi Covid 19 leasing melalui deb kolektor menarik secara paksa kendaraan yang menjadi onjek jaminan fidusia dari tangannya tanpa ada pemberitahuan terlebih dahulu kepada debitur. Padahal dalam klausul perjanjian leasing ditentukan apabila debitur wanprestasi, perusahaan leasing sebagai kreditur sebelum melakukan eksekusi untuk melakukan somasi kepada debitur untuk melakukan prestasinya. Ketentuan ini tidak dindahkan oleh, niat baik dari debitur untuk membayar cicilannya tidak ditanggap oleh perusahaan leasing. Perusahaan leasing tutup karena Kondisi Covid 19, debitur berhadapan dengan deb kolektor, deb kolektor akan menyerahkan kembali kendaraan kepada debitur apabila, debitur mau membayar uang penarikan sejumlah 7 juta ditambah dengan uang cicilan kredit kendaraan yang belum dibayar dan selanjutnya perjanjian dapat dilanjutkan kembali. Kondisi ini sungguh tidak manusia, perusahaan leasing telah melakukan pelanggran hukum dan perjanjian leasing yang telah disepakati.

Selanjutnya Pasal 1 angka 2 Undang-Undang Nomor 42 tahun 1999 tentang Jaminan Fidusia, menyatakan jaminan fidusia adalah hak jaminan atas benda bergerak baik berwujud maupun tidak berwujud dan benda tidak bergerak khususnya bangunan yang tidak dapat dibebani dengan hak tanggungan sebagaiman yang dimaksud dengan Undang-Undang Nomor 4 Tahun 1996 tentang Hak Tangggungan tetap berada dalam pengusaan Pemberi Fidusia. Kedudukannya pemberi kredit atau penerima fidusia diutamakan dalam pelunsasan utang terhadap kreditur lainnnya.

Pada perjanjian kredit yang diikat dengan jaminan fidusia terdiri dari pemberi kredit atau penerima fidusia dan penerima kredit atau Pemberi fidusia. 
Pemberi fidusia adalah orang perorangan atau korporasi pemilik benda yang menjadi objek jaminan fidusia (Pasal 1 angka 5). Sedangkan penerima fidusia adalah orang perseorangan atau korporasi yang mempuyai piutang yang pembayarannya dijamin dengan jaminan fidusia (Pasal 1 angka 6).

Jaminan fidusia merupakan perjanjian antara debitur atau pemberi fidusia dengan kreditur atau penerima fidusia yang menimbulkan kewajiban bagi debitur atau pemberi fidusia untuk memenuhi prestasi.yang sudah disepakati dalam perjanjian fidusia. ${ }^{5}$ Sebagai objek jaminan fidusia adalah benda bergerak baik berwujud maupun tidak berwujud dan benda tidak bergerak yang tidak dapat dijadikan jaminan dengan Hak Tanggungan.

Apabila pemberi fidusia melakukan cidera janji, penerima fidusia dapat melakukan eksekusi jaminan fidusia sesuai ketentuan dengan yang diatur dalam Pasal 29 Undang-Undang 42 Tahun 1999. Namun kenyataan lembaga pembiayaan (leasing) dalam menjalankan bisnisnya melakukan perjanjian kredit yang diikat dengan jaminan fidusia. Dalam perjanjian kredit dengan jaminan fidusia, apabila penerima kredit melakukan cidera janji, maka untuk melakukan eksekusi terhadap objek jaminan fidusia diatur dalam Pasal 29 Undang-Undang Nomor 42 Tahun 1999. Namun kenyataan masih ditemukan perusahaan pembiayaan (leasing) yang melakukan eksekusi terhadap objek jaminan tidak sesuai ketentuan Pasal 29 Undang-undang Nomor 42 Tahun 1999. Perusahaan leasing secara sepihak melakukan tindakan sewenang- wenang, secara paksa dengan mengunakan jasa deb kolektor melakukan eksekusi objek jaminan. Deb kolektor menarik kendaraan sebagai jaminan objek jaminan fidusia secara paksa tanpa pemberitahuan terlebih dahulu kepada debitur sebagai pemberi fidusia.

Dengan terbitnya Putusan MK Nomor 18/PUU/XVII/2019) membawa perubahan baru terhadap tata cara pelaksanaan eksekusi objek jaminan. Penerima fidusia atau kreditur tidak dapat lagi melakukan eksekusi objek jaminan secara sepihak, bertindak sewenang -wenang, secara paksa mengunakan jasa deb kolektor menarik objek jaminan dari tangan debitur atau pemberi fidusia yang cidera janji. Putusan Mahkamah Konstitusi (MK) Nomor 18/PUU-XVII/2019 pada tanggal 6 Januari 2020 tentang uji materil Undang-undang Nomor 42 Tahun

\footnotetext{
${ }^{5}$ Pasal 4 Undang-Undang Nomor 42 Tahun 1999 tentang Jaminan Fidusia.
} 
1999 Pasal 15 ayat (2) dan ayat (3), membuat sebagian perusahaan pembiayaan (leasing) resah, karena tidak boleh lagi melakukan eksekusi sendiri (parate eksekusi) terhadap objek Jaminan Fidusia.

Dengan adanya putusan Mahkamah Konstitusi Nomor 18/PUU-XXVII/2019 telah membawa perkembangan hukum baru pelaksanaan objek jaminan fidusia, hal ini yang menjadi menjadi latar belakang penulis untuk menulis tentang" Eksekusi Jaminan Fidusia Setelah Putusan Mahkamah Konstitusi Putusan MK Nomor 18/PUU/XVII/2019).” Rumusan masalah, bagaimana pelaksaaan eksekusi jaminan fidusia setelah terbitnya Putusan MK Nomor 18/PUU/XVII/2019). Tujuan penulisan adalah untuk mengetahui ketentuan hukum pelaksaaan eksekusi jaminan fidusia setelah terbitnya Putusan MK Nomor 18/PUU/XVII/2019).

\section{METODE PENELITIAN}

Metode penelitian yang digunakan dalam penulisan adalah penelitian kepustakaan dengan mengunakan data sekunder yang berkaitan dengan jaminan fidusia berupa bahan hukum primer berupa peraturan perundang-undangan dan putusan pengadilan Mahkamah Konstitusi, bahan hukum sekunder berupa bukubuku, internet dan bahan hukum tertier berupa kamu hukum. Dalam melakukan penelitian penulis mengunakan pendekatan Undang-Undang (statute approach). Pendekatan undang-undang adalah menelaah semua undang-undang dan regulasi yag bersangkut paut dengan isu yang sedang ditangani. ${ }^{6}$ Pendekatan undangundang dilakukan dengan menelaah undang-undang dan regulasi yang berkaitan dengan Jaminan fidusia yaitu, Undang-Undang Dasar Tahun 1945, UndangUndang Nomor 42 Tahun 1999 tentang Jaminan Fidusia dan Putusan MK Nomor 18/PUU/XVII/2019) tentang uji materil Undang-undang Nomor 42 tahun 1999. Selain itu penulis mengunakan pendekatan komperatif dengan membanding eksekusi jaminan fidusia berdasarkan Undang -Undang Nomor 42 Tahun 1999 sebelum dan setelah Putusan MK Nomor 18/PUU/XVII/2019) tentang Uji materiil Undang-Undang Nomor 42 tahun 1999. Data sekunder yang diperoleh dari hasil penelitian kepustakaan dianalis secara sistematik, ilmiah untuk menjawab isu

${ }^{6}$ Peter Mahmud Marzuki, Penelitian Hukum, Cet-9, ( Jakarta: Prenada Media Group, 2014), hal. 131. 
yang berkembang yang dirumuskan dalam rumusan masalah. Penelitian yang dilakukan bersifat yuridis normatif, jenis penelitian bersifat kualitatif.

\section{PEMBAHASAN}

\section{Eksekusi Jaminan Fidusia Sebelum Putusan MK Nomor 18/PUU-XVI/2019} MK

Eksekusi jaminan fidusia sebelum putusan Mahkamah Konstitusi, dilakukan apabila debitur atau pemberi fidusia melakukan cidera janji atau wanprestasi. Debitur dalam keadaan cidera janji atau wanprestasi artinya debitur tidak dapat memenuhi kewajiban sebagaimana yang ditetapkan dalam perikatan atau perjanjian. Tidak dipenuhi kewajibannya disebabkan dua hal, pertama karena kesalahan debitur baik disengaja maupun karena kelalaian, kedua karena keadaan memaksa (Overmacht/ Forcemajeur). ${ }^{7}$ Ada empat keadaan wanprestasi yaitu; tidak memenuhi prestasi; terlambat memenuhi prestasi; memenuhi prestasi secara tidak sah; melakukan sesuatu yang menurut perjanjian tidak sah.

Dalam suatu perjanjian debitor dianggap wanprestasi apabila apabila tenggang waktu yang ditentukan dalam perjanjian telah terlampaui waktunya. Namun demikian menurut Pasal 1238 KUHPerdata masih memerlukan teguran tertulis dari pengadilan (somasi) baru dapat dikatakan debitur dalam keadaan wanprestasi. Pasal 1238 KUHPerdata ini tidak berlaku lagi oleh Surat Edaran Mahkamah Agung Nomor 3 / 1963. Menurut Subekti cukup ditegur secara pribadi atau secara lisan oleh krediturnya agar debiturnya melakukan prestasinya. ${ }^{8}$

Dalam praktek terdapat kasus lembaga pembiayaan (leasing) dalam menjalankan bisnisnya apabila debitur cidera janji/ wanprestasi, perusahaan leasing tidak melakukan teguran baik secara lisan maupun secara tertulis sebagaimana pendapat Subekti, tapi perusahaan langsung melakukan eksekusi tanpa somasi dengan mengunakan jasa deb kolektor. Perusahaan leasing yang

${ }^{7}$ Djaja S. Meliala, Perkembangan Hukum Perdata tentang Benda dan Hukum Perikatan, Cet.1, ( Bandung, Nuansa Mulia, 2015), hal. 75.

${ }^{8} \mathrm{Ibid}$, hal 76. 
menyewa jasa deb kolektir melakukan eksekusi objek jaminan dengan cara paksa menarik kendaraan secara sepihak yang mengarahkan kepada tindak pidana.

Berdasarkan Pasal 11 Undang-Undang Nomor 42 Tahun 1999 tentang Jaminan Fidusia, benda yang dijadikan jaminan fidusia wajib untuk didaftarkan pada kantor pendaftaran fidusia di kantor Kementerian Hukum dan HAM. Permohonan pendaftaran dilakukan oleh penerima fidusia (Pasal 13 ayat (1). Setelah dilakukan pendaftaran, kantor pendaftaran fidusia menerbitkan sertifikat jaminan fidusia yang sama dengan tanggal penerimaan permohonan fidusia (Pasal 14 Undang-Undang Nomor 42 Tahun 1999 tentang Jaminan Fidusia. Pada serifikat jaminan fidusia terdapat kata-kata" Demi Keadilan Berdasarkan Ketuhanan Yang Maha Esa" (Pasal 15 ayat 1). Sertifikat jaminan fidusia mempunyai kekuatan eksekutorial yang sama dengan putusan pengadilan yang telah berkekuatan hukum tetap (Pasal 15 ayat 2). Berdasarkan Pasal 15 ayat (1) apabila penerima fidusia tidak mendaftarkan jaminan pendaftaran fidusia pada kantor pendaftaran fidusia, maka jaminan fidusia tersebut tidak mempunyai kekuatan eksekutorial dan tidak dapat dilakukan eksekusi secara paksa melalui pengadilan apabila debitur melakukan wanprestasi.

Jadi pendaftaran fidusia bertujaun untuk melindungi kepentingan kreditur sebagai penerima fidusia apabila debitur pemberi fidusia melakukan wanprestasi, kreditur dapat melakukan eksekusi secara paksa terhadap objek jaminan fidusia. Selanjutnya Pasal 15 ayat (3) menyatakan apabila debitur cidera janji, penerima fidusia mempunyai hak untuk menjual benda yang menjadi objek jaminan Fidusia atas kekuatannya sendiri. Berdasarkan Pasal 15 ayat (3), penerima fidusia dapat melakukan parate eksekusi dengan cara menjual objek jaminan fidusia atas kekuatan sendiri secara sepihak tanpa kompromi terlebih dahulu dengan pihak debitur yang cidera janji. Hal ini juga bertentangan dengan pendapat Subekti yang menyatakan sebelum debitur dikatakan melakukan wanprestasi, kreditur terlebih dahulu untuk melakukan teguran baik secara lisan atau tertulis. Pasal 15 ayat (2) dan ayat (3) Undang-Undang Nomor 42 Tahun 1999 tentang Jaminan Fidusia hanya melindungi kepentingan kreditur tapi tidak melindungi kepentingan debitur.

Dalam praktek masih ditemui lembaga pembiayaan dalam menjalankan kegiatan bisnisnya apabila debitur cidera janji sebelumnya tidak dilakukan 
somasi agar debitur melakukan prestasinya, tapi langsung mengeksekusi dengan mengunakan jasa deb kolektor. Jadi berdasarkan uraian di atas disimpulkan, bahwa debitur pemberi fidusia dikatakan berada dalam keadaan cidera apabila debitur pemberi pemberi fidusia tidak memenuhi prestasinya sebagai yang telah diperjanjikan. Pemberi fidusia melakukan eksekusi objek jaminan fidusia apabila debitur pemberi fidusia telah melakukan cidera janji atau wanprestasi. Kekuatan eksekutorial pada sertifikat fidusia mempunyai kekuatan eksektorial sama dengan putusan hakim yang berkuatan tetap dan kreditur dapat melakukan eksekusi secara paksa sepihak (parate eksekusi), hal ini tentu akan merugikan kepada pihak debitur pemberi fidusia.

Sebelum berlakunya Putusan MK Nomor 18/ PUU-XVII/ 2019, eksekusi jaminan fidusia diatur berdasarkan Pasal 29 ayat (1) menyatakan, eksekusi terhadap jaminan fidusia dapat dilakukan dengan cara; a, pelaksanaan titel eksekutorial, pada sertifikat sertifikat fidusia terdapat kata-kata " Demi Keadilan Berdasarkan Ketuhaann yang Maha Esa" mempunyai kekuatan eksekutorial sama dengan putusan pengadilan yang berkekuatan hukum tetap: b. penerima fidusia atau kreditur dapat melakukan penjualan benda yang menjadi jaminan objek jaminan atas atas kekuasaan penerima fidusia melalui pelelangan umum dan mengambil pelunasannya piutanganya dari hasil penjualan; c. dan penjualan dibawah tangan yang dilakukan berdasarkan kesepakatan pemberi dan penerima fidusia dengan cara demikian diperoleh dengan harga yang tertinggi yang menguntungkan kepada para pihak.

Berdasarkan Pasal 29 ayat (1) tersebut diatas disimpulkan, bahwa eksekusi jaminan fidusia dapat dilakukan dengan 3 (cara) cara yaitu: pelaksananaan titel eksekutorial, penjualan benda objek jaminan fidusia atas kekuasaan penerima fidusia dan penjualan dibawah tangan yang dilakukan berdasarkan kesepakatan pemberi dan penerima fidusia dengan cara demikian dapat diperoleh harga yang tertinggi yang menguntungkan kepada para pihak. Pasal 29 ayat (2) menyatakan, pelaksanaan penjualan objek jaminan dibawah tangan sebagaimana yang dimaksud Pasal 29 ayat (1) huruf c dilakukan setelah lewat waktu 1 (satu ) bulan sejak diberitahukan secara tertulis oleh pemberi dan penerima fidusia kepada 
pihak yang berkepentingan dan diumumkan dalam 2 (dua) surat khabar yang beredar di daerah yang bersangkutan.

Pasal 15 ayat (2) Undang -Undang Nomor 42 Tahun 1999 tentang Jaminan Fidusia, sertifikat fidusia yang terdapat kata-kata " Demi Keadilan Berdasarkan Ketuhanan Yang Maha Esa” mempunyai kekuatan yatan eksekutorial yang sama dengan putusan pengadilan yang telah memperoleh kekuatan hukum yang tetap. Jadi jika debitur pemberi fidusia cidera janji, sertifikat fidusia yang memuat irah-irah “ Demi Keadilan Berdasarkan Ketuhanan Yang Maha Eda” dapat dilakukan eksekusi secara paksa melalui pengadilan. Selanjutnya Pasal 15 ayat (3) menyatakan, apabila debitur cidera janji penerima fidusia mempunyai hak untuk menjual benda yang menjadi jaminan objek jaminan fidusia atas kekuasaan sendiri. Berdasarkan Pasal 15 ayat (3) Undang-Undang Nomor 42 Tahun 1999 memberikan hak-hak kepada penerima jaminan fidusia atau kreditur untuk menjual sendiri barang jaminan tanpa harus ada putusan pengadilan atau parate executie apabila debitur atau pemberi fidusia melakukan wanprestasi. Jadi sebelum Putusan MK Nomor 18/ PUU-XVII/ 2019 eksekusi objek jaminan dilakukan berdasarkan Pasal 29 Undang-Undang Nomor 42 Tahun 1999. Kreditur penerima fidusia dapat melakukan eksekusi secsra sepihak atau parate eksekusi apabila debitur cidera janji. Dalam praktek lembaga pembiyaan eksekusi secara pihak perusahaan mengunakan jasa deb kolektor.

Dalam pelaksanaan titel eksekutorial, eksekusi dilakukan melalui pengadilan, sedangkan parate eksekusi tidak memerlukan perantaraan pengadilan, namun penerima fidusia bisa langsung menjual dengan cara-cara tertentu yang diatur dalam undang-undang seperti lelang atau melalui bursa (untuk sahamsaham dan efek yang diperdagangkan di pasar modal, pengaturan cara penjualan tertentu ini bertujuan untuk melindungi kepentingan debitur atau pemberi fidusia.

\section{Eksekusi Jaminan Fidusia Setelah Putusan MK Nomor 18/PUU-XVI/2019}

Tanggal 6 Januari 2020 Majelis Hakim Mahkamah Konstitusi mengucapkan Putusan Perkara uji materil terhadap Undang-Undang Nomor 42 Tahun 1999 tentang Jaminan Fidusia. Putusan Mahkam Konstitusi, mengabulkan permohonan para Pemohon untuk sebagian" menyatakan beberapa frasa beserta 
penjelasannya pada Pasal 15 ayat (2) dan Pasal 15 ayat (3) Undang -Undang Nomor 42 Thun 1999 tentang Jaminan Fidusia bertentangan dengan Undang Undang Dasar Tahun 1945. Frasa-frasa yang dimaksud yaitu, frasa "kekuatan eksekutorial" sama dengan putusan pengadilan yang berkekuatan hukum tetap yang diatur pada Pasal 15 ayat (2) dan frasa "cidera janji" yang terdapat pada Pasal 15 ayat (3) UU Fidusia. ${ }^{9}$

Putusan Mahkamah Konstitusi, menyatakan Pasal 15 ayat (2) kata- kata “ kekuatan eksekutorial" dan putusan pengadilan yang berkuatan hukum tetap bertentangan dengan Undang Undang Dasar Tahun 1945 dan tidak mempunyai kekuatan hukum yang mengikat sepanjang tidak dimaknai tidak ada kesepakatan dalam hal cidera janji dan debitur keberatan menyerahkan secara sukarela objek yang menjadi jaminan fidusia, maka pelaksanaan prosedur hukum pelaksanaan eksekusi jaminan fidusia harus dilakukan dan berlaku sama dengan eksekusi putusan pengadilan hukum yang berkekuatan hukum tetap. Sebaliknya jika klausul cidera janji sudah ada kesepakatan di awal antara debitur dengan kreditur, maka perusahaan pembiayaan dapat melakukan eksekusi sendiri tidak melalui pengadilan. Jadi setelah adanya putusan Mahkamah Konstitusi, kreditur tidak dapat lagi melakukan eksekusi secara sepihak terhadap objek jaminan fidusia harus melalui Pengadilan Negeri, kecuali jika ada kesepakatan cidera janji diawal antara debitur dengan kreditur dan debitur menyerahkan secara sukarela objek jaminan fidusia kepada kreditur.

Mahkamah Konstitusi juga, menyatakan terhadap frasa "cidera janji" sebagaimana diatur dalam Pasal 15 ayat (3) UU Jaminan Fidusia, bertentangan dengan UUD 1945 dan tidak mempunyai kekuatan hukum mengikat sepanjang tidak dimaknai bahwa "adanya cidera janji tidak ditentukan secara sepihak oleh kreditur melainkan atas dasar kesepakatan antara kreditur dengan debitur atau atas dasar upaya hukum yang menentukan telah terjadinya cidera janji". Jadi parate eksekusi setelah putusan Mahkamah Konstitusi tetap bisa dilaksanakan asal ada kesepakat antara debitur dengan kreditur dan debitur menyeahkan objek eksekusi secara sukarela.

\footnotetext{
9 https://www.djkn.kemenkeu.go.id/kpknl-bekasi/baca-artikel/12953/putusan-mahkamahkonstitusi-nomor-18puu-xvii2019-apa-implikasinya-bagi-proses
} 
Lebih lanjut Mahkamah Konstitusi juga berpendapat, bahwa meskipun dalam permohonan uji materil diminta untuk dilakukan pengujian atas ketentuan dalam Pasal 15 ayat (2) Undang-Undang Jaminan Fidusia, namun dengan telah dinyatakannya inkonstitusional terhadap frasa "kekuatan eksekutorial" dan frasa "sama dengan putusan pengadilan yang berkekuatan hukum tetap" dan frasa "cidera janji" dalam Pasal 15 ayat (3) Undang-Undang Nomor 42 tahun 1999, maka Mahkamah Konstitusi, menyatakan bahwa Penjelasan Pasal 15 ayat (2) UU Jaminan Fidusia, frasa "kekuatan eksekutorial" bertentangan dengan UndangUndang Dasar Tahun 1945 dan tidak mempunyai kekuatan hukum mengikat sepanjang tidak dimaknai "terhadap jaminan fidusia yang tidak ada kesepakatan tentang cidera janji dan debitur keberatan menyerahkan secara sukarela objek yang menjadi jaminan fidusia, maka segala mekanisme dan prosedur hukum dalam pelaksanaan eksekusi Sertifikat Jaminan Fidusia harus dilakukan dan berlaku sama dengan pelaksanaan eksekusi putusan pengadilan yang telah berkekuatan hukum tetap.

Setelah Putusan Mahkamah Konstitusi No 18/PUU-XVII/2019 Penerima hak fidusia atau kreditur penerima fidusia tidak boleh melakukan eksekusi sendiri (Parate eksekusi) melainkan harus mengajukan permohonan pelaksanaan kepada Pengadilan Negeri. Parate eksekusi dapat dilakukan apabila ada kesepakatan tentang cidera janji yang telah ditentukan diawal dan debitur bersedia menyerahkan objek jaminan fidusia secara sukarela. Putusan Mahkamah Konstitusi menyatakan tidak semua eksekusi objek jaminan fidusia harus dilakukan melalui pengadilan. Terhadap jaminan fidusia yang tidak ada kesepakatan mengenai cidera janji (wanprestasi) antara kreditur dengan debitur, dan debitur keberatan menyerahkan objek jaminan fidusia secara sukarela, maka segala mekanisme dan prosedur hukum dalam pelaksanaan eksekusi sertifikat jaminan fidusia harus dilakukan dan berlaku sama dengan putusan pengadilan yang berkuatan hukum yang tetap.

Jika tidak ada kriteria wanprestasi yang disepakati antara debitur dan kreditur dalam isi perjanjian, debitur enggan menyerahkan objek jaminan fidusia kepada kreditur, maka pengadilan menjadi penengah untuk memberi izin eksekusi apabila syarat telah dipenuhi. Tidak semua penarikan objek jaminan harus 
dilakukan melalui pengadilan, karena akan berakibat pengadilan kebanjiran dalam menangani kasus eksekusi objek jaminan fidusia disamping itu banyak kasus-kasua lainnya yang harus diselesaikan oleh pengadilan.

Eksekusi objek jaminan fidusia dapat dilakukan oleh perusahaan pembiayaan (leasing) selama terdapat kesepakatan klausul wanprestasi (cidera janji) dan debitur secara sukarela menyerahkan objek jaminan fidusia, maka parate eksekusi dapat dilakukan..Putusan Mahkamah Konstitusi tidak menggugurkan kekuatan eksekutorial perusahaan pembiayaan, jika tida terdapat kesepakatan cidera janji, misalnya debitur tidak membayar cicilan pada saat tertentu dan tidak mau menyerahkan secara sukarela objek jaminan fidusia, maka dapat dilakukan eksekusi secara paksa melalui pengadilan.

Pasal 15 ayat (3) menyatakan, jika debitur cidera janji, pemberi fidusia mempunyai hak untuk menjual objek jaminan fidusia. Mahkamah Konstitusi menentukan cidera janji tidak ditentukan sepihak oleh kreditur melainkan atas dasar kesepakatan dengan debitur. Jika terdapat kesepakatan cidera janji, maka eksekusi jaminan fidusia tidak boleh dilakukan sendiri oleh penerima fidusia (kreditur) melainkan harus mengajukan permohonan eksekusi ke Pengadilan Negeri. Putusan Mahkamah Konstitusi bertujuan memberikan kepastian hukum dan rasa keadilan antara pihak leasing dengan debitur serta mencegah tindakan sewenang- wenang dalam pelaksanaan eksekusi oleh pihak kreditur..

Sebagaimana telah diuraikan di atas, bahwa setelah Putusan Mahkamah Konstitusi penerima hak fidusia tidak boleh lagi melakukan eksekusi sendiri melainkan harus mengajukan permohonan pelaksanaan kepada Pengadilan Negeri. Putusan Mahkamah Konstitusi menyatakan tidak semua eksekusi objek jaminan fidusia harus dilakukan melalui pengadilan tapi dapat juga dilakukan parate eksekusi. Klasul perjanjian fidusia tidak mengatur klasul kesepakatan cidera janji (wanprestasi) antara kreditur dengan debitur, dan debitur keberatan menyerahkan objek jaminan fidusia secara sukarela, maka segala mekanisme dan prosedur hukum dalam pelaksanaan eksekusi jaminan fidusia harus dilakukan dan berlaku sama dengan putusan pengadilan yang berkuatan hukum yang tetap.Sebaliknya jika tidak ada kriteria kesepakatan cidera janji dalam klausul 
perjanjian fidusia dan debitur enggan objek jaminan disita kreditur, maka eksekusi dilakukan melalui pengadilan negeri.

Penarikan objek jaminan tidak selalu harus dilakukan melalui pengadilan, misalnya perusahaan leasing memberikan kredit motor pada saat jatuh tempo pembayaran debitur tidak dapat melakukan pembayaran cicilan motornya, maka leasing dapat menraik kendaraannya apabila debitur yang cidera janji secara sukarela menyerahkan motornya. Namun apabila debitor tidak mau menyerahkan secara sukrela motor sebagai objek jaminan fidusia, maka perusahaan leasing tidak dapat melakukan penarikan motor secara sepihak tapi harus mengajukan permohonan ke pengadilan negeri untuk melakukan eksekusi terhadap objek jaminan fidusia. Putusan Mahkamah Konstitusi ini tidak menggugurkan kekuatan eksekutorial perusahaan pembiayaan ,jika terdapat cidera janji, misalnya debitur tidak membayar cicilan pada saat tertentu. Pasal 15 ayat (3) menyatakan jika debitur cidera janji, pemberi fidusia mempunyai hak untuk menjual objek jaminan fidusia secara sepihak tidak mempunyai kekuatan hukum lagi, tapi eksekusi dapat dilakukan setelah kreditur (leasing) mengajukan permohonan eksekusi melalui pengadilan negeri.

Berdasarkan putusan Mahkamah Konstitusi, cidera janji yang ditentukan sepihak oleh kreditur idak berdasarkan kesepakatan dengan debitur, maka eksekusi jaminan fidusia tidak boleh dilakukan sendiri oleh penerima fidusia (kreditur) (Parate eksekusi) melainkan harus mengajukan permohonan ke Pengadilan Negeri. Putusan ini demi memberikan kepastian hukum dan rasa keadilan antara pihak kreditur dengan debitur serta mencegah tindakan kesewenangan wenangan dalam pelaksanaan eksekusi oleh kreditur. Putusan Mahkamah Konstitusi No 18/PUU-XVII/2019 yang menyatakan kreditur (leasing) tidak bisa lagi secara sepihak mengeksekusi atau menarik objek jaminan fidusia seperti kendaraan atau rumah, hanya berdasarkan sertifikat jaminan fidusia. Mahkamah Konstitusi memutuskan lembaga pembiayaan (leasing) yang ingin menarik kendaraan harus mengajukan permohonan kepada Pengadilan Negeri. Namun Mahkamah Konstitusi menyatakan Kreditur tetap bisa melakukan eksekusi sepihak asalkan debitur mengakui adanya cidera janji (wanprestasi) dan secara sukarela bersedia menyerahkan objek jaminan 
fidusianya. Putusan Mahkamah Konstitusi tidak menghilangkan hak eksekutorial pada Pasal 15 Undang-undang Nomor 42 Tahun 1999 asal debitur yang cidera janji secara sukarela menyerahkan objek jaminan fidusia. ${ }^{10}$

Setelah putusan Mahkamah Konstitusi No. 18/PUU-XVII/2019 kemungkinan permasalahan timbul, pada saat kreditur mengajukan permohonan eksekusi objek jaminan fidusia ke Pengadilan Negeri,sebelum putusan putusan Eksekusi Jaminan Fidusia dari Pengadilan Negeri, debitur atau pemberi fidusia yang mempunyai itikad tidak baik dapat saja dengan sengaja menghilang objek jaminan fidusia atau debitur pindah alamat yang tidak dapat lagi dilacak keberadaannya oleh kreditur, sehingga merugikan kepada pihak kreditur (perusahaan pembiayaan).

Selain itu kemungkinan masalah lain yang timbul adalah jika setiap melakukan eksekusi jaminan objek jaminan fidusia, penerima fidusia atau kreditur harus mengajukan permohonan eksekusi jaminan fidusia ke pengadilan, akan menyebabkan beban tugas dari Pengadilan Negeri akan bertambah banyak, apakah setiap Pengadilan Negeri akan mampu menangani kasus permohonan eksekusi yang diajukan oleh perusahaan leasing. Pada hal kasus-kasus yang ada selama ini cukup banyak yang akan diselesaikan oleh Pengadilan Negeri, tentu hal ini akan menyebabkan putusan permohonan pelaksaaan eksekusi jaminan eksekusi memakan waktu yang lama juga dan dapat menjadi celah bagi pemberi fidusia yang beritikad tidak baik untuk melakukan perbuatan yang dapat merugikan kepada penerima fidusia.

Pemberi fidusia yang mempunyai itikad tidak baik akan memanfaatkan waktu yang lama tersebut untuk mengalihkan objek jaminan fidusia, misalnya dengan cara menjual kendaraan dengan harga yang rendah tanpa BPKB, berpindah alamat yang sulit atau tidak dapat lagi dilacak keberadaannya oleh penerima fidusia. Situasi seperti ini tentu akan merugikan kepada perusahaan leasing sebagai penerima fidusia yang telah beritikad baik melakukan eksekusi jaminan fidusia sesuai putusan Mahkamah Konstitusi.

Solusi yang dapat diambil oleh kreditur untuk mencegah kemungkinan itikad tidak baik pemberi fidusia, berdasarkan Putusan Mahkamah Konstitusi,

\footnotetext{
${ }^{10} \mathrm{https}: / /$ www.kompasiana.com/tomspeed/5e5203dad541df6b7f2e68a2/mengupasputusan-mk-no-18-puu-xvii-2019, diakses tanggal 27 April 2020, pukul 14.00
} 
penerima fidusia tidak harus mengajukan permohonan eksekusi ke Pengadilan Negeri untuk melakukan eksekusi objek jaminan terhadap pemberi fidusia yang melakukan cidera janji. Penerima fidusia dalam ini perusahaan leasing dapat mengunakan Pasal 15 ayat (3) menyatakan, jika debitur cidera janji, penerima fidusia mempunyai hak untuk menjual objek jaminan fidusia atas kekuatan sendiri (Parate eksekusi). Berdasarkan Pasal 15 ayat (3) penerima fidusia dapat melakukan parate eksekusi dengan syarat apabila telah ada kesepakatan mengenai cidera janji dan pemberi fidusia bersedia menyerahkan objek jaminan fidusia secara sukarela. Penerima fidusia tidak boleh melakukan eksekusi objek jaminan sepihak secara sepihak. Jika tidak diperjanjikan terlebih dahulu dan debitur fidusia bersedia menyerahkan objek jaminan fidusia secara sukarela.

Namun kenyataan dalam praktek, penerima fidusia masih banyak ditemukan pelanggaran yang dilakukan oleh kreditur apabila pemberi fidusia melakukan cidera janji, perusahaan leasing sebagai penerima fidusia melakukan parate eksekusi secara pihak tanpa pemberitahauan kepada pemberi fidusia, bahkan mengunakan jasa deb kolektor yang jelas bertentangan dengan hukum. Penerima fidusia melakukan pemaksaaan penarikan kendaraan dengan mengunakan jasa deb kolektor tersebut, tanpa pemberitahuan terlebih dahulu dan kompromi dengan pemberi fidusia. Poisisi debitur dalam hal ini berada pada posisi yang lemah dengan berat menyerahkan objek jaminan fidusia berupa kendaraan kepada deb kolektor.

Dan jika pemberi fidusia masih tetap berkeingan melanjutkan kreditnya, perusahaan leasing membebani debitur untuk membayar jasa penarikan kendaraan oleh deb kolektor ditambah kredit yang belum dibayar. Perusahaan leasing hanya menentukan secara sepihak dan tidak diatur dalam perjanjian melakukan tindakan sewenang-wenang tidak sesuai prosedur hukum yang merugikan kepada debitur yang berada pada posisi yang lemah. Tindakan dari penerima fidusia dalam hal ini leasing sudah jelas bertentangan dengan eksekusi jaminan Fidusia sebagaimana yang diatur dalam Pasal 29 Undang-Undang Nomor 42 Tahun 1999 tentang Jaminan Fidusia dan Putusan Mahkam Konstitusi No. 18/PUU-XVII/2019 tentang penarikan objek jaminan fidusia terhadap pemberi fidusia yang melakukan wanprestasi. 


\section{PENUTUP}

\section{Kesimpulan}

Sebelum Putusan Mahkam Konstitusi No. 18/PUU-XVII/2019 eksekusi jaminan fidusia berlaku Pasal 29 dapat dilakukan beberapa cara; a. titel eksekutorial pada sertifikat sertifkat fidusia “Demi Keadilan Berdasarkan Ketuhanan yang Maha Esa" mempunyai kekuatan eksekutorial sama dengan putusan pengadilan yang berkekuatan hukum tetap; b. penerima fidusia dapat melakukan penjualan benda yang menjadi jaminan objek jaminan atas atas kekuasaan penerima fidusia melalui pelelangan umum dan mengambil pelunasannya piutanganya dari hasil penjualan; c. penjualan dibawah tangan yang dilakukan berdasarkan kesepakatan pemberi dan penerima fidusia dengan harga yang tertinggi yang menguntungkan kepada para pihak.

Setelah Putusan Mahkamah Konstitusi No. 18/PUU-XVII/2019 eksekusi jaminan fidusia, menyatakan Pasal 15 ayat (2) frasa " kekuatan eksekutorial" dan putusan pengadilan yang berkuatan hukum tetap bertentangan dengan UUD Tahun 1945. Kreditur penerima fidusia tidak dapat melakukan eksekusi secara sepihak atas objek jaminan fidusia, tapi harus mengajukan permohonan eksekusi ke Pengadilan Negeri. Frasa "cidera janji" yang terdapat pada Pasal 15 ayat (3) Undang-Undang Jaminan Fidusia, bertentangan dengan UUD 1945 dan tidak mempunyai kekuatan hukum mengikat. Kreditur tidak dapat melakukan eksekusi jaminan objek jaminan fidusia secara sepihak, kecuali jika telah disepakati antara kreditur dengan debitur dalam cidera janji dan debitur bersedia menyerahkan objek jaminan secara sukarela.

\section{Saran}


Untuk menghindari tindakan sewenang -wenang dari kreditur atau penerima fidusia melakukan eksekusi objek jaminan dalam hal pemberi fidusia cidera janji, sebaiknya kreditur melakukan somati sampai tiga kali kepada pihak debitur yang cidera janji. Jika debitur tidak mengindahkan somasi, maka kreditur dapat melalukan parate eksekusi dengan syarat berdasarkan kesepakatan para pihak untuk menjual objek jaminan melalui pelelangan umum dengan harta tertinggi yang menguntungkan kepada kedua belah pihak. Jika upaya parate eksekusi tidak berhasil jalan terakhir eksekusi dilakukan dengan mengajukan permohonan eksekusi melalui Pengadilan Negeri

Otoritas Jasa keuangan untuk memberikan sanksi kepada lembaga pembiayaan (leasing) yang melakukan eksekusi objek jaminan dengan mengunakan jasa deb kolektor. Tindakan deb kolektor termasuk tindak pidana, karena menarik objek jaminan fidusia dari tangan debitur dengan cara paksa. Perjanjian dapat dilanjukan apabila debitur bersedia membayar uang jasa penarikan deb kolektor yang besarnya telah ditentukan oleh perusahaan leasing ditambah .dengan tunggakan uang cicilan kredit yang harus dibayar oleh debitur. Hak ini sungguh memberatkan kepada debitur. 


\section{DAFTAR PUSTAKA}

\section{BUKU}

Hasbullah, Frieda Husnis Hasbullah, Hukum Kebendaan Perdata, Cet.2, Jakarta: Ind-Hill-Co, 2005.

Marzuki, Peter Mahmud, Penelitian Hukum, Cet-9, Jakarta: Prenada Media Group, 2014.

Meliala, Djaja S, Perkembangan Hukum Perdata tentang Benda dan Hukum Perikatan, Cet.1, Bandung: Nuansa Mulia, 2015.

Prajitno. Andreas Albertus Andi. Hukum Fidusia, Cet.10 Malang: Selaras, 2010

Prajitno.A.A. Andi, Hukum Fidusia, Cet.1, Malang: Bayumedia Publishing, 2009

Suharnoko, Hukum Perjanjian Teori dan Analisis Kasus. Cet.6, Jakarta: Prenada Media Group, 2009

Widjaya, Gunawan \& Ahmad Yani, Jaminan Fidusia, Jakarta: RajaGrafindo, 2007.

Peter Mahmud Marzuki, Penelitian Hukum, Cet-9, Jakarta: Prenada Media Group, 2014.

\section{Peraturan dan Putusan}

Undang-Undang Dasar Negara Republik Indonesia Tahun 1945

Undang -Undang Nomor 42 Tahun 1999 tentang Jaminan Fidusia

Putusan Mahkamah Konstitusi No 18/PUU-XVII/2019

Himpunan Peraturan Fudusia \& Hak Tangggungan. Jakarta: Indonesia legal Center Publishing, 2008.

\section{Internet}


https://www.kompasiana.com/tomspeed/5e5203dad541df6b7f2e68a2/mengupasputusan-mk-no-18-puu-xvii-2019, diakses pada tanggal 27 April 2020 . https://www.djkn.kemenkeu.go.id/kpknl-bekasi/baca-artikel/12953/putusanmahkamah-konstitusi-nomor-18puu-xvii2019-apa-implikasinya-bagi-proses, diakses pada tanggal 27 April 2020.

https://www.hukumonline.com/talks/baca/lt5e295466bd93e/wanprestasi-daneksekusi-objek-jaminan-fidusia--best-practice-setelah-putusan-mahkamahkonstitusi-nomor-18-puu-xvii-2019/, diakses pada tanggal 27 April 2020. 